Prof. E. W. MacBride said that if Darwin had produced no other book than his journal of researches during the voyage round the world of H.M.S. Beagle, he would have shown himself to be one of the finest naturalists that ever lived, and his description in this work of the Galapagos Islands and of their fauna is a most masterly production. Prof. MacBride proceeded to refer to the giant tortoises, the lizards and the birds, and said that Darwin was at an utter loss to account for the prodigality of creative power which had resulted in the different islands having distinct species of tortoises and birds. Later Darwin applied his theory of natural selection to the explanation of the occurrence of the variety of species in the different islands. Prof. MacBride expressed his strong dissent from this explanation and from Sir Edward Poulton's views, and concluded by stating that in his opinion the ultimate cause of difference in species is difference in habits and in reaction.

Mr. H. W. Parker recalled Darwin's statement that the reptiles of the Galapagos gave "the most striking character to the zoology of these islands". During the last century, the number of species of reptiles was found to be greater than Darwin had realised, but the increased knowledge emphasises what he considered "by far the most remarkable feature in the natural history of this archipelago - - that the different islands to a considerable extent are inhabited by a different set of beings". Mr. Parker, in giving an account of the present distribution of the reptiles in the islands, stated that of the fourteen species of giant tortoises, three are probably extinct and most of the others exceedingly rare. The curious marine lizards (Amblyrhynchus) and the land lizards (Conolophus) are also in grave danger of extermination. Man has been the principal destructive agent in the past, but the future of all species, large and small, is jeopardised by the presence on the islands of introduced pigs, dogs, rats and cats which have run wild. That the remnants of the fauna are in imminent danger has been realised by the Government of Ecuador, which has passed decrees proclaiming certain of the islands as 'asilos reservados', and also giving protection to all the interesting indigenous species throughout the archipelago. Mr. Parker urged that only international co-operation could make this legislation effective, and that the British Association should initiate action to this end.

\title{
An Early Stone Age Culture of America
}

$\mathrm{R}^{\mathrm{E}}$ EFERENCE to the discovery of 'Folsom points' and to 'Folsom man' in the archæological literature of the United States from time to time within the last decade has given rise to an expectation that it might be possible, within a comparatively short time, to construct some sure and certain foundation for the claim to a relatively high antiquity for early man in America, which has often been advanced, but never satisfactorily substantiated. Since the Folsom point was first recognised in 1927 as an early and specific stone age industry of North America, occurring on occasion in association with a presumedly early fauna, later discoveries and further study of its characteristics and distribution have given clearer definition to the archæological problem and indicated the direction of intensive search for the geological and palæontological data upon which the solution of the chronological problem ultimately will depend.

Passing reference has been made in the columns of NATURE from time to time to the discovery of evidence relating to Folsom man. Such evidence was by no means always such as to carry conviction, nor did it give, although the 'point' itself is sufficiently characteristic, any clear impression of a specific cultural phase. Such uncertainties, however, are now to a great extent removed by the recent examination and partial excavation by Frank H. H. Roberts, Jr., archæologist of the Bureau of American Ethnology, of a Folsom midden in a locality now particularised as the Lindenmeier Site, twenty-eight miles north of Fort Collins, in northern Colorado. His report* has not only made important and substantial additions to knowledge of the Folsom culture and technique, but it has also crystallised previous evidence and affords opportunity for review of the data relating to the Folsom culture as a whole.

It may not be out of place to point out that, while it is now possible, thanks to Mr. Roberts's new evidence, to form a fairly clear conception of the Folsom phase of culture, Folsom man is unknown. No human skeletal remains have been discovered in association with Folsom artefacts as yet.

In the light of the evidence from the Lindenmeier Site, as will appear later, there is now justification

* "A Folsom Complex: Preliminary Report on Investigations at the Lindenmeier Site in Northern Colorado". Smithsonian Misc. Collect., 94, No. 4. 
for speaking of a 'Folsom culture' of which the existence previously had been a matter of inference only, from the type of a single class of implement, and of which the picture even yet is not complete in detail. It is the culture of a hunting people closely associated with the bison. A concurrence of evidence, geological, palæontological and archæological, points to the conclusion that not only does it represent an earlier phase in the American cultural sequence than that of the 'Basket-Makers' of the Pueblo area, hitherto regarded as the earliest to appear in the southwest, but also that in the instance of the Folsom implements a case for a quaternary dating has been made out with a closer approach to certainty than in any other culture of the American stone age.

The Folsom point, the characteristic implement of the culture, is of a triangular, or rather leafshape, in which the greatest breadth lies between the tip and the middle point of the blade. In size, it varies from $17 \mathrm{~mm}$. to $75 \mathrm{~mm}$. in length, $14 \mathrm{~mm}$. to $32.5 \mathrm{~mm}$. in breadth and $3 \mathrm{~mm}$. to $6 \mathrm{~mm}$. in thickness. A variant form has rather a wider range in size. The material is varied, chalcedony, jasper, chert, quartzite, petrified wood, moss agate, geyserite (rare) and white sandstone, all being recorded.

The indigenous inhabitants of North America have always been essentially a stone-using people. Even the native copper area of Lake Superior developed a chalcolithic rather than a true metal culture. Within living memory, stone implements continued to be made in California in full view of the railway track. In the course of their long history of stone using, the Indians developed many eccentric forms of implement, for which anthropologists, in default of a better understanding, have been content perforce to accept the designation 'ceremonial' ; but of all the implements fashioned for practical use, probably none is more distinctive than the 'Folsom point'. Its peculiar characteristic is a longitudinal groove, or channel, running down the middle of the blade, which leaves a ridge on each side parallel with the edge. As the two faces of the typical implement are identical in form, this gives it in section the shape of a double concave. The sides are prolonged at the base to form wings, making the base a semi-circular gap or notch.

The form of the point, obviously the tip of a projectile weapon, either arrow or spear, made it peculiarly liable to fracture. The vast majority of the implements of this type which have been found are broken, only the tip or the butt-end being found. The predominance of the butt-end on the Lindenmeier Site no doubt was due, as Mr. Roberts has suggested, to a practice of retrieving the shaft of the weapon and bringing it back to camp to fit a new point. The purpose of the remarkable channel is unknown, although the groove in the modern bayonet at once suggests an analogy.

A brief reference to the course of research which has led up to Mr. Roberts's investigation, will not be out of place, especially as, in so far as it relates to the question of distribution, it has a bearing on the interpretation of the evidence relating to the Folsom culture which needs further elucidation.

As already mentioned, the specific character of the Folsom point was established in 1927. Before that date, and indeed so far back as 1897, the peculiar features of the implement had been noted ; but as the specimens were mostly surface finds, their significance had not been appreciated. In 1925, the attention of J. D. Figgins, director of the Colorado Museum of Natural History, was directed to a bone deposit on the upper sources of the Cimmaron River near Folsom, New Mexico. Investigations in the following year brought to light evidence which seemed to demonstrate beyond question the definite association of stone artefacts and an extinct bison. Additional 'points' were found in 1927 by investigators working on behalf of the Colorado Museum, and Dr. Barnum Brown of the American Museum of Natural History found one specimen still embedded in the matrix between two of the ribs of an animal skeleton, where it still remains on exhibition in the Colorado Museum. It was seen in situ by Dr. A. V. Kidder, as well as by Mr. Roberts. It was then agreed that not only could the association not be questioned, but also that the points were totally different from the ordinary types of stone implement hitherto found in the south-west.

In the following year (1928), joint operations by the American Museum of Natural History and the Colorado Museum under Dr. Barnum Brown and Dr. Clark Wissler were made the occasion of an informal conference of geologists, palæontologists and archæologists, who arrived at the generally accepted conclusion that the Folsom find indicated an earlier appearance for man in the south-west than had hitherto been allowed. It was under date of this year that the first account of the Folsom point appeared in Europe in an article by E. B. Renaud on the antiquity of man in North America in L'Anthropologie, 38, 23-49.

Of later activity in the study of the problem and search for further evidence, mention may be made of the work in New Mexico of E. B. Howard, of the Pennsylvania University Museum, and of Prof. E. B. Renaud, of the University of Denver, and his students in their archæological survey of Colorado and Nebraska. The former has found in a cave in the Guadalupe Mountains in the southeastern part of New Mexico a Folsom point in conjunction with musk ox and an animal of the 
musk ox group. These occurred in a stratum underlying a level containing Basket Maker material. This find thus established definitely the priority of the Folsom culture. At the same time, the musk ox being a cold-climate animal, it is generally considered to be evidence of the contemporaneity of Folsom man with an Ice Age fauna. Further investigations by Mr. Howard near Clovis, New Mexico, also point to the coexistence of Folsom man and an extinct fauna; but here the evidence is considered open to question, and until it has been published in fuller detail, must be regarded as still sub judice.

On the general question of the quaternary age of the Folsom implements and the associated extinct fauna, opinion is at present divided. While some would see in this association evidence for the existence of man in America in late Pleistocene times, others maintain that it points rather to a late survival of Ice-Age animals into recent periods, and that there is no evidence that man was actually present in America in the Ice Age.

Of Prof. Renaud's investigations, what must be regarded as the most important outcome to date is a distinction in the character of the culture which he recently claims to have established. This differentiates the Yuma point from the Folsom point. The former, on the basis of typology, he considers to be older than the Folsom. The two occur in association on many sites as surface finds, and their relative antiquity is still under discussion.

We may now turn to Mr. Roberts's investigations on the Lindenmeier Site, which must be regarded as one of the most important contributions of recent years to prehistoric archæology in America.

The Lindenmeier Site was first discovered by Judge C. C. Coffin and his son, A. L. Coffin, in 1924. From it they collected some 83 points or portions of points, as well as about the same number of other artefacts. They were not, however, then aware of the significance of the former ; and it was not until 1930 that they were informed by Prof. E. B. Renaud that they were Folsom points. Further surface finds were made afterwards; but it was only in 1934, when the site was examined by Mr. Roberts, that any intensive investigation was attempted. The finds by members of the Coffin family had been made in a restricted area, some 70 yards by 150 yards in extent; but the point at which Mr. Roberts's excavations were carried out lies apart from this area, and is situated in the side of a ravine or gully about a quarter of a mile away. Here an undisturbed and intact layer of midden material was found at about $14 \mathrm{ft}$. below present groundlevel and about $12 \mathrm{ft}$. above the bed of the gully. This was partially excavated in October and part of November, 1934 ; and it is hoped to carry the work further on a future occasion. The midden lies at the deepest point of an implementiferous area lying between the edge of the gully and a terrace, and covering ground approximately 250 yards by 200 yards. The objects of bone and stone are found just above a clay stratum in a layer six inches to one foot in thickness. Except at the midden, where was the main concentration of archæological material, finds over this area are in the nature of chance accumulations.

Of the actual finds, the Folsom points both whole and fractured, as well as flakes and specimens spoiled in making, have afforded Mr. Roberts material for pertinent suggestions as to the obscure technique of manufacture upon which it is not possible to touch here. A large proportion of the other artefacts are scrapers, of which there are several varieties. Some show minute and careful chipping, others are rough and crude. Most belong to the curved end, or 'thumb-nail' type. Of the side-scrapers some are almost paper-like in their thinness. While there is no definite knowledge as to the uses to which some of these scrapers, such as the turtleback and the side scraper, were put, they would serve for dressing skins as well as for knives, gouges, adzes or abrading tools. One of the most interesting types is a graver, an implement familiar in European archæology; but no other evidence is to hand of the practice of the graver's art by Folsom man. Most of these gravers are fortuitous flakes, which have been modified by chipping a small sharp point on one side or end. Some, however, are more definitely shaped. A number of specimens among the implements are classified as knives. The best are carefully chipped blades, which exhibit typical Folsom characteristics in their fluted faces and the marginal retouch. Several of them are made from the channel flakes resulting from the manufacture of points. Among other implements are blades and choppers. Miscellaneous objects include pieces of sandstone showing signs of use-there is no material of this character in the neighbourhood-pieces of hæmatite, smooth and striated from rubbing (a good indication that they supplied pigment material) nodules with battered ends (no doubt hammers) and a number of fragments of bone, which had served as tools.

Most of the bone material was scrappy. Bison, fox, rabbit and wolf have been identified. It is noted as a matter of considerable interest that the bison is identical with the two extinct forms found at Folsom, Stelabison occidentalis taylori and Bison oliverhayi.

It will be seen that the excavations which have been carried out by Mr. Roberts on the Lindenmeier Site have extended very considerably knowledge of this stone-using, hunting culture, in which 
future excavation may well fill in further detail. One point remains to be mentioned. On determination of the specific character of the Folsom point and the advancement of its claim to a high antiquity, attention was directed, as already mentioned, to the fact that it was already known, in one instance at least, having received the name of the "Seneca River point". It was shown to have a wide distribution-from southern Canada to the Gulf of Mexico and from the Rockies to the Atlantic. Further study, however, has demonstrated that the true Folsom points are confined to the High Plains on the eastern slope of the Rockies, while the more widely distributed point is a larger, more generalised form, centring notably in the Finger Lakes section of New York State, in Ohio, Tennessee and southern Virginia. The affiliation and the chronological and distributional relation of the two forms are problems which are now being made the subject of study by $\mathrm{Mr}$. Roberts.

Until the typological and chronological relations of the two forms of point are established with some degree of precision, no finality in the interpretation of the archæological evidence is attainable. Tentatively, however, it may be pointed out that the evident antiquity and the known distribution of the true Folsom point are consistent with the view that it is a specialised form developed by the people who, it has been suggested, penetrated to the south-west in the period of transition at the close of the Ice Age along a corridor on the eastern slopes of the Rockies. It will be interesting to see if the researches in Siberian archæology, upon which Mr. E. B. Howard is to engage, produce any typological evidence of an Asiatic ancestry for this remarkable American type of implement.

\section{The Percy Sladen Expedition to Lake Huleh}

$\mathrm{H}^{2}$ ULEH is a shallow lake lying in the northern end of the Jordan Valley, where it extends towards Mount Hermon. The sides of this valley are formed here by two parallel ranges of mountains, but at the south end of the lake the valley is closed by low hills except where the Jordan has cut a deep gorge into Lake Tiberias, the fall to which is 600 feet. The actual lake is approximately five miles long by three across, and is roughly pear-shaped, with its broad end to the north. Its maximal depths are 10-12 feet, but its greater part is not more than $4-5$ feet. On its east side the mountains, which are basaltic, commence their rise close to the lake, and the shore is rocky, much large material being carried down the numerous water-courses. On the west side, a broad plain extends out from the lake, for the strong winter torrents have brought down quantities of gravel, which form spits projecting into the lake. Over most of the central area, the bottom of the lake is of soft grey mud, which is largely populated by plants of Potamogeton. At the extreme south, there is a small area where Phragmites dominates, and this also grows on the eastern side in isolated patches. On both sides of the lake there are numerous springs, and some cold patches in the lake are supposed to mark further effluents.

The lake is bounded on its northern side by a large swamp, through which the Jordan flows as a swift stream, even in the dry season. The swamp begins as a band of floating lilies (Nuphar) across its north end, extending down each side for half a mile. On the inside of the lilies, the plant succession is at present being studied. The swamp is not homogeneous in structure, and its most striking feature is the papyrus, which over large areas is the dominant plant form. Through it, progression is only possible along waterways, which are kept open by the Arabs, who use it for many purposes. The swamp consists of a mass of roots, much matted and bound together with plant debris in various stages of decomposition. The roots appear to be floating in the water, and it is easy to sink waist deep through masses of debris, where the papyrus is not too thick. At various places clear pools are found, these apparently due to springs. At the sides of the swamp the land is being reclaimed by Arabs for the planting of maize and millet.

The channel of the Jordan runs down the middle of the northern swamp, where heavier silt has been deposited during the floods of the rainy season. Local observations suggest that the swamp is extending southwards and encroaching on the lake, almost as if pushed by the processes of reclamation on its shores. One of the most striking features of the lake is the large quantity of fine silt brought down by the Jordan, when irrigation is occurring further up the valley. It is of a light grey colour, and quite different from the mud formed by plant decomposition. It is deposited generally over the lake, and forms in addition a broad bar across its northern end. 